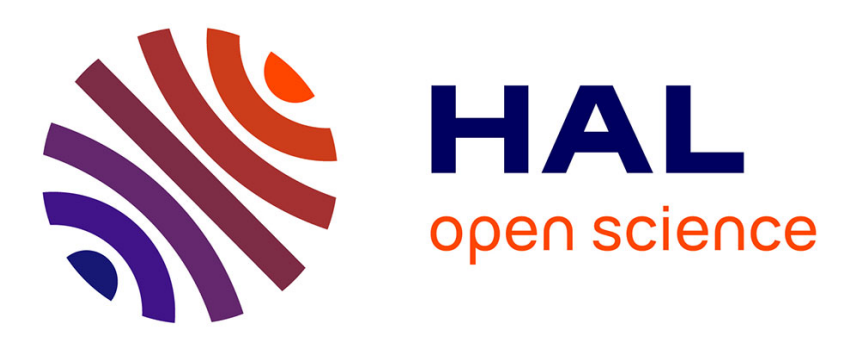

\title{
Governing comfort in France: from hygienism to sustainable housing XXth-XXIst century
}

Yankel Fijalkow

\section{To cite this version:}

Yankel Fijalkow. Governing comfort in France: from hygienism to sustainable housing XXth-XXIst century. Housing Studies, 2018, 34 (6), pp.1021-1036. 10.1080/02673037.2018.1509947 . hal02552656

\section{HAL Id: hal-02552656 \\ https://hal.science/hal-02552656}

Submitted on 29 Apr 2020

HAL is a multi-disciplinary open access archive for the deposit and dissemination of scientific research documents, whether they are published or not. The documents may come from teaching and research institutions in France or abroad, or from public or private research centers.
L'archive ouverte pluridisciplinaire HAL, est destinée au dépôt et à la diffusion de documents scientifiques de niveau recherche, publiés ou non, émanant des établissements d'enseignement et de recherche français ou étrangers, des laboratoires publics ou privés. 


\title{
Governing comfort in France: from hygienism to sustainable housing XXth-XXIst century
}

\author{
Yankel Fijalkow \\ Department of Social Science, Centre de Recherche sur I'Habitat, Paris, France
} Q1

\begin{abstract}
This article intends to present the notion of comfort as a central element in housing policies. Comfort is liable to an analysis in terms of governance and enrichment of the Housing Regimes theory. Thereby it develops in the first part a socio-historical analysis of housing standards production patterns in France from the 19th century to current day. It distinguishes the hygienist period, the modernist period and the environmental period. For the latter, it shows how private and institutional stakeholders operate. In the second part it analyses the results of a qualitative and quantitative survey of one thousand French homeowners. It reveals the various acceptations of the notion of comfort and the diverse integration of the energy conservation targets in practices. A new social differentiation appears through the capabilities to use new technologies and control the environment.
\end{abstract}

\section{ARTICLE HISTORY}

Received 29 November 2016 Accepted 27 July 2018

\section{KEYWORDS}

Comfort; housing policy; standards; energy saving; housing practices

The notion of Housing Regime describes the connection between spheres of action (production, distribution, and management) and integrated actors (public/private) Q3 (Kemeny, 1992, 13) . It establishes a method for comparing (Angel, 2000) Welfare regime guarantee as well as the promotion of occupancy status (Allen et al., 2008). It helps to understand the decision-making levels between the central authority and local authorities. Thanks to the notion of 'regime' (Elkin, 2015; Stone, 1993), alliance setups between actors can be assessed in order to analyse their 'collective capacity to govern' (Le Galès, 1995; Mossberger, 2009).

However, this notion does not include in its pattern the values and the social practices that dovetail with political guidance. In this article, we wish to put into perspective these aspects by showing that a central element of these policies, namely housing comfort, is the subject of governance from the various actors (Table 1).

From this perspective, our approach integrates Michel Foucault's theory (2004) on the governability of bodies and the power of panopticism in housing inasmuch as comfort equipment (sanitary equipment in the nineteenth century, home automation in the twenty-first century) organizes household practices. However, we distance ourselves from an intentionalist perspective. We consider housing comfort as an interdisciplinary and professional field (Bourdieu, 1979) that is subject to negotiations, 
Table 1. Periodization of the French policies about comfort.

Hygenist period (1950-1950)
A prescriptive application of the laws against unhealthy housing
A network of stakeholders appointed by the State
A regulatory policy with regard to sanitary facilities and social
occupancy.
Sanitation, in order to improve working class living standards
(and productivity).
Healthy social housing as an education tool for the work-
ing class
Housing sanitary comfort levels improved dramatically
A dramatic increase in construction
Social housing as a virtuous model.
An uninterrupted increase in the household income spent on
housing.
Renting regulations imposed by public authorities included
housing standards
1973: first oil crisis, first thermal regulation bill for building (RT).
Brundtland report (1988), Rio conference (1992), Aalborg
Charter (1994): Energy governance in housing.
Grenelle Environmental Summit (bill, 2007): State, local com-
munities, NGOs, employers, and inter-branch national bodies
move to "a performance-based approach"
A new "certified" professional standards market : technical per-
formance, and good practices
Incentives in order to encourage habitants to « save energy »
(and fight « fuel poverty »)

A prescriptive application of the laws against unhealthy housing

anitation, in order to improve working class living standards (and productivity)

ealthy social housing as an education tool for the work-

A dramatic increase in construction

Social housing as a virtuous model.

An uninterrupted increase in the household income spent on

housing standards

Brundtland report (1988), Rio conference (1992), Aalborg

Charter (1994): Energy governance in housing. move to "a performance-based approach"

formance, and good practices (and fight " fuel poverty »)

translations and recompositions (Akrich et al., 2006; Latour, 1996). Thus, comfort, which is expressed through standards, reveals the power relations between the actors (State, landlords, professional organizations,). But it reveals also the practices of the dwellers that have a memory of standards but depend on equipment imposed by the current political direction. However, they have the ability to stand firm against them.

Indeed, the notion of standard regarding housing corresponds to several levels. First, requirements pertaining to construction, such as room size and sanitation; second behavioural social requirements such as hygiene rules. Standards are therefore imposed as much on builders that have to comply with a certain quality to enter the marketplace as on dwellers to enter a housing unit and not be expelled. Additionally, although some standards that mainly aim at making housing units exchangeable on the marketplace pertain to the notion of norm, they are also concerned by social practices that differentiate housing units. Indeed, the housing standardisation process that is supported by the installation of equipment (sanitation, ventilation, lighting, heating ...), is necessarily confronted with dwellers' practices.

Standards and norms are thus at the centre of the housing policy as it was organised by the State when it first appeared in the nineteenth century in the fight against housing insalubrity and the construction of social housing. Today, this policy works as a field structured by agents, positions and action rules, and the State still plays an important if not dominant part. In France, the Civil Code, the Housing and Urban Planning Code (in the name of Public Health and planet preservation, and of the quality of the National territory), provide the definition of 'good housing unit'. But it has been defined more recently by private actors through 'labels' that certify housing quality in terms of energy consumption. In the way of Bourdieu, one can thus speak 
of a housing normative field that involves prime contractors and contracting authorities, landlords, local authorities, associations (McKee, 2011). All assert jurisdiction over stating what is 'good housing'. Over the past few years, this field has become more and more complex with the arrival of private actors and environmental construction standards that address both construction quality and households' energy practices. In France, as in other European countries, a decentralisation of standards is taking place regarding both local authorities and private actors (Bevir et al., 2003).

At the same time, the notion of comfort has changed at individual level. According to the historian John E. Crowley (2001) the notion of comfort introduced in the 19th century in Great-Britain and in the USA, embraces a technical definition: 'a self-conscious satisfaction with the relationship between one's body and its immediate physical environment'. As shown by Miller (1983) regarding suburbanisation in the US, throughout the 20th century, comfort became more and more technology-based, integrating equipment (sanitary, appliances, recreational) and systems (running water, heating, ventilation, home automation) involving energy expenditure.

In this way, Olivier Le Goff (1994) shows that the idea of economic development and of comfort are interconnected in such a way that comfort is seen as a legitimate outcome of progress and a way of proclaiming social status. In France, the National Institution of Statistics, INSEE, has classified comfort items ever since the 1946 census, taking into account whether or not there is a kitchen, facilities, a toilet, and power supply connection, gas system connection, water supply network connection, mains drainage connection.

This quote shows that it is a set of technical, social and cultural mediations established as social standard that shapes the notion of comfort according to the collective depiction of a period. This is what Elizabeth Shove (2003) points out, suggesting analysing instead the dynamics that lead to the search for comfort and what defines it rather than supposedly objective factors. Her generational and cultural analysis highlights differentiated relationships to technical tools, consumption, social distinction and well-being. Paying close attention to people's culture and to household history, she points out homogenisation factors. But her analysis of individual behaviours needs to be extended by the more macro-social study of living space production.

We thus wish to shift the scientific debate on Housing Regimes that has focused on occupancy statuses and mechanisms of population (Kemeny, 1995) and that Q5 regards State intervention as central (Groves, 2016; Harloe, 2008). In order to show how comfort is ensured we shall first develop a historical perspective that repositions the State in the context of the various actors associated with comfort (I). This will enable us to better understand social practices in the context of social inequalities in housing and new practices, particularly in regard to heating, which are the ones that are the most required of households (II).

In this perspective, this article will build on historical documentation from institutions in charge of housing in France and on the secondary analysis of a survey by questionnaire and hearings carried out by a professional organisation specializing in home automation. Such a study should involve a representative sample of one thousand homeowners occupying their property in accordance with a representative sampling of the age and region structures. Having performed the role of scientific 
consultant for this organization, which led us to provide methodological advice and to comment on results, we shall build on the conditions of this survey and its quantitative and qualitative results published online. ${ }^{1}$ In this framework, our comment on this survey, which is significant in terms of number of households interviewed, puts these results in a socio-historical perspective. In doing so, it also sheds light on the sometimes difficult dialogue between the sociologist-researcher and contemporary comfort technicians.

\section{France housing regime: from hygienism to sustainable development}

A brief panorama of the French Housing Regime seems necessary to understand these results. In view of the debates on Housing Regimes, France occupies a particular place. The position of housing within State budget actually corresponds to 32,4 Billion Euros split between 15,5 aimed at households, 6,3 Billion for housing renovation, 5 Billion Euros aimed at supporting social construction, 2 Billion towards Home ownership, 2 Billion encouraging rental investment, 1,6 Billion for the accommodation of vulnerable household. The fact that there is a stock of $18 \%$ of social housing financed by public authorities and offered to a population defined by its income level (which is evaluated to 61\%) shows a strong State involvement in favour of the middle and working classes (Bugeja-Bloch, 2013). Faced with the impoverishment process of the population living in social housing (Driant \& Rieg, 2004) the strategy of organisations and local authorities consist in reinforcing construction for the employed middle class. By advantageous tax deduction allowances, different laws promote the renting investment of the private individuals (Pollard, 2010). Social home ownership ${ }^{2}$ has been booming since the 2000s after having gone through a long period during which it mainly drew middle and high income households (Lambert, 2015). 58\% of French households are property owners, and benefit from significant investment, that can be compared to other countries (Crawford \& McKee, 2016). The private rental sector (20\%) that has been subjected to strong rental regulations (1948 law) is still qualify for public subsidies for renovation (Lévy-Vroelant \& Fijalkow, 2014). It also bears the mark of State intervention. These three features of the French Housing Regime exemplify the difficulty in branding it either as a social housing regime, or as a regime in favour of access to private propriety and a lesser State intervention.

Getting a better grasp of the Housing Regime cannot therefore only consist in being interested in housing distribution according to the various social layers particularly in a context of change in the role of the State (Blanc, 2004). It is also a matter of looking into its quality as well as into the nature of the actors that participate in defining criteria including dwellers' strategies. Comfort standards, that are commensurate with the legal status of this quality, constitute a fundamental issue with regard to housing equipment and location, its price, and the nature of the population. They are fundamental in urban renovation policies. In the 1960s, the fight for housing healthiness motivated the renewal of the old working class areas. Today, comfort standards are also an issue when renovating social housing neighbourhoods and for energy related upgrades in housing. In those two contexts, the content of standards conforms to the structure of the players involved: State, local authorities, builders, 
property developers, administrators, professional associations, and financial organisations.

Thanks to these elements of definition, the evolution of the French Housing Regime can be better understood through history in terms of quality and standards including the technical, social and economic aspects.

Understanding hygienist-housing standards requires understanding its emergence in the framework of the Housing Policy put in place in the 19th century. It followed several paths whether it is nonstandard housing market elimination, compulsory authorization for housing construction, or standardised housing production, particularly for council housing. It is supported by a network of stakeholders appointed by the state and a regulatory policy with regard to sanitary facilities and social occupancy.

Therefore, hygienist standards that developed as of the mid-nineteenth century are characterized by their prescriptive application. In a context of considerable tension around public health, one of the founding principles of public action, they were based on promoting new sanitary facilities and, among housing rules, banishing the lack of privacy. These elements brought closer doctors and engineers in charge of public and private spaces sanitation, of the construction of underground sanitary systems, and of wastewater treatment in the greater suburbs. The sanitation issue drove the social dimension in order to improve working class living standards (and productivity).

These standards were the subject of negotiations between experts as shown by the story of the 1850 law on unhealthy housing (Fijalkow, 2000) as well as similar measures in the United Kingdom (Howden-Chapman, 2004). In France, this law that arose from a wave of epidemic (including cholera in 1832) did not enact standards but made specialized committees responsible for visiting, further to a complaint, tenements whose characteristics were 'likely to endanger the life or the health of its tenants'. Owners could be sentenced to carry out works and these committees, anxious to standardize their decisions, gradually defined universal and measurable healthiness criteria such as sanitary facilities in the building and the tenement, drinkable water and wastewater systems, lighting in the living space, and their minimum size.

In Paris, these standards resulted in the statistics developed as of the 1891 census. At the turn of the century, Pasteur's theories were gaining currency and led to the setting up of the 'casiers sanitaires des maisons' (collected information about houses regarding sanitary issues) thanks to which unhealthy buildings and blocks could be spotted, because of the mortality rate due to tuberculosis, attributed to the density of buildings in big cities where light cannot break through. This measure targeted city centres but did not turn from residential areas that were spontaneously extending in the outskirts of cities and in the suburbs. The 1902 law, first public Health text, stipulates in its housing section that standards related to premises habitability are compulsory for the issuance of a building permit (Fijalkow, 2000).

Council housing that officially arose in France as of the 1912 Bonnevay law aims at making of healthy housing an education tool for the working class (Magri, 1991). Standards from Council housing intended for families moved out of slums and unhealthy blocks are characterized by their sobriety and their Spartan nature however scrupulously healthy (Flamand, 1989). The idea was to educate these families, to teach 
them to dwell in one-bedroom apartments that may not have exceeded $30 \mathrm{~m}^{2}$. But social landlords, who were also in charge of accommodating middle class families, had to provide more spacious and more comfortable housing. A combination, among others, of these options was given by Henri Sellier, former head of the HBM (old French Council Housing) for the Département de la Seine (old area encompassing Paris and its immediate suburbs) and former minister, in an article written in 1944 for the social reformers of the Musée Social. ${ }^{3}$

In France, the 30 years of post-war economic boom were marked by real estate regulation in which council housing was seen as a virtuous model. Progress was made possible thanks to a dramatic increase in construction from 1954 to 1972 with 550,000 new homes built that year. It was also made easier thanks to an uninterrupted increase in the household income spent on housing that was only $10 \%$ in 1960 (tenants and first time buyers). This evolution was facilitated by the enforcement of building and renting regulations and by housing standards imposed by public authorities (State and local communities) on builders, lessors and tenants. Under the influence of the laws regulating leases $(1948,1978)$, funding for households (housing benefit) and for lessors (in particular social housing landlords) regulations heightened the housing standardization effort undertaken in the early 1900s by the hygienist movement.

Consequently, between 1950 and 1975, housing sanitary comfort levels improved dramatically (Jacquot, 2006). Whereas at the end of the war, 10\% of the housing had a bathtub or a shower and barely more than $25 \%$ toilets inside the apartment, this rate exceeded $98 \%$ in 2002 for those facilities. Several other additional improvements paralleled this continuous increase in the comfort level, such as larger living space, fewer occupiers, household appliances, the soaring number of outbuildings (basements, garages, terraces, gardens...) but also the development of DIY projects for home design and decoration. Moreover, striving for comfort has led to the improvement of soundproofing and thermal insulation, good ventilation, and temperature levels in the rooms.

1973 marked a turning point with the return of the private market, of housing engineers, of dwellers individual responsibility and energy consumption reduction becoming a priority. It was further to the first oil crisis that France adopted in 1974 its first thermal regulation (RT). This strategy, which was urgently designed further to the dramatic increase in hydrocarbons prices, was amended four times (1982, $1988,2000,2005,2012$ ) in order to gradually strengthen thermal efficiency criteria enforced for new buildings. This turning point occurred before the Brundtland report (CEMD, 1988) was published, which advocated 'development that meets the needs of the present without compromising the ability of future generations to meet their own needs'. The Rio conference in 1992, made legitimate and operational the concept of sustainable development at national level. As early as 1994, the European Community adopted the Aalborg Charter that included in its agenda city and energy governance in housing. Construction, which amounts to $44 \%$ of energy consumption in France and contributes to global warming through greenhouse effect, is at the heart of debates. Proposals have sprung up supporting HQE (high quality environmental standards) housing. As of 2007, laws that came out of the Grenelle Environmental 
Summit involve the state, local communities, NGOs, employers, and inter-branch national bodies in order to move from 'a performance-based approach to a requirement-based approach' as it is often presented in these texts.

In this context, official and professional bodies have sprung up using new 'certified' standards to ensure technical performance. Approved by the consumer code, these new standards validate know-how and good practices. Although these certified standards are not legally binding, their adoption by the contracting authority bears witness to the will to deliver a product of superior and controlled quality. The Certification becomes therefore a market product from the moment these contracting authorities place their trust in it and local communities, concerned with the promotion of their eco-neighbourhoods attractiveness, refer to it.

These certifications are often created by professional associations such as, in France, Qualitel Association founded in 1974 upon request of the Ministry of Housing with consumer associations, public bodies and professionals. Effinergy Association was founded in 2006 by Regional authorities that wanted, as developers, a product that could compare to the brands used in Europe: Minergie in Switzerland and Passivhaus in Germany. Its first label, launched in 2007, has had a strong impact on stimulating the development of French thermal regulation. The target of average energy consumption of $50 \mathrm{kWhep} / \mathrm{m}^{2} /$ year was embraced by the state. Although the label is not mandatory, it reflects the will of the contracting authority to deliver a higher quality and controlled product. However, it has become a market component, since the state agreement eco tax favours developers, real estate stakeholders, and local authorities interested in promoting the attractiveness of their eco neighbourhoods (Lelong and Mallard, 2000). The race for the 'best sustainable bidder', leads to recognising that labels, developed by economic and industrial stakeholders of the building sector have to anticipate technical State regulation.

A race for the 'best sustainable bidder' is now under way between economic and industrial stakeholders of the construction industry and local communities, which is preempting the state technical regulation for the issuance of a construction permit. Simultaneously, a message of good dwelling practices standardization is gaining currency (Renauld, 2014), which enshrines empowerment and individuation of practices: individual heating metering, individual breakdown of maintenance charges, etc. In social housing, new tools are proposed to the dwellers in order to save energy. Finally, the State has put in place multiple tax schemes and support for owners to encourage energy retrofits in the housing stock built before WW II (30\% of housing in France). The National Agency for Housing Improvement (ANAH), founded in 1971, has been committed since 2009 to operating the incentive plan for the execution of energy-conservation renovations by owner-occupants. All these new technical and financial schemes in favour of sustainable housing call for an adjustment of dwellers' lifestyles (Shove, 2010).

But these technical labels that reflect industrial agreements and a reshaping of the stakeholders systems are also consumption standards. These standards are comfort standards: housing in France is now well equipped in terms of sanitary facilities and living spaces are increasing: heating is the main issue, because of its cost which can be a housing vulnerability. The quality of construction is emphasised but also 
households' behaviours. Public institutions present the standard thermal heating to 19 degrees Celsius as optimal since it has been the topic of scientific discussion within the World Human Organization since the 1950's (Goromosov, 1954). For the ADEME (French Environment and Energy Management Agency), the objective is to fight the expansion of fuel poverty that currently affects nearly 4 million households that spend more than $10 \%$ of their income to be heated. Given the expected increase in fuel prices, the construction of energy efficient housing is a preventive measure. Council housing bodies have developed information with limited success (Renauld, 2014). New homes private owners are confronted with technical devices. A study conducted by an official organization, the Commissariat Général au développement durable (General Commission for Sustainable development) has noted that the construction extra cost of sustainable housing standards is of $14 \%$ in individual housing and of $9 \%$ in collective housing. ${ }^{4}$

Therefore, as we are witnessing the emergence of a new role for the State, more and more inclined towards incentive (and less coercive) actions, and the emergence of local stakeholders in sustainable housing, dwellers' individual responsibility is alluded to in order to explain resistance to change in the perception of comfort in housing. Thus, the standard reduction desired by many public and private actors accompanies public action to explain good practices to households. And these answer differently according to their cultural uses of energy, their relations with institutions (public and private donors, energy suppliers) and their own sense of comfort.

\section{Social practices and new housing inequalities}

How have these transformations in the governance affected households' practices? To what extent do new policies erase habits acquired upon old measures?

In fact, while the right to appropriate housing is stated in article 25 of the Universal Declaration of Human Rights, ${ }^{5}$ statistics, which summarize housing issues, that is overcrowding, equipment deprivation (such as the absence of a bathtub or a toilet), a roof leaking inside the dwelling or housing considered too dark, show there are 5.5\% vulnerable households within the EU in 2009 (Wattson \& Turkington, 2014). This housing quality indicator has been put in place in accordance with the proportion of individuals living in a dwelling seen as overcrowded, while having at the same time at least one of the housing deprivation marks mentioned above. It may be surprising that these statistics do not capture any phenomena related to housing fragility such as energy precariousness, which has yet been condemned by numerous authors and organisations (Healy, 2004).

These discrepancies between law and official statistics show how difficult it is to define housing conditions despite more than 150 years of thinking within the states (Desrosières \& Naisch, 2002, Fijalkow, 2000). Public actors that have since the nineteenth century set the conditions for considering housing liveable or not and implemented urban renovation operations, do not follow the same logic as statisticians who shed light on public authorities with regard to the living conditions of households. They also dovetail with the assessment that housing inequality has increased in developed countries and worldwide (Habitat III, issue paper $\mathrm{n}^{\circ} 20$ 'Housing') and 
Table 2. Date, status and sector of construction and energetic label (2014)

\begin{tabular}{|c|c|c|c|}
\hline & $\begin{array}{l}\text { Labels performance } \mathrm{F} \text { and } \mathrm{G} \\
\text { (low performance) }\end{array}$ & $\begin{array}{l}\text { Other dwelling } \\
\text { (classes A à D) }\end{array}$ & Total \\
\hline Built before 1948 & $\begin{array}{c}3567446 \\
(38 \%)\end{array}$ & $\begin{array}{c}5843097 \\
(42 \%)\end{array}$ & $\begin{array}{c}9388016 \\
(100 \%)\end{array}$ \\
\hline Apartments & $\begin{array}{c}4124403 \\
(44 \%)\end{array}$ & $\begin{array}{c}7830395 \\
(66 \%)\end{array}$ & $\begin{array}{c}11954794 \\
(100 \%)\end{array}$ \\
\hline $\begin{array}{l}\text { Bedsits and one } \\
\text { bedroom flats }\end{array}$ & $\begin{array}{c}2778190 \\
(29 \%)\end{array}$ & $\begin{array}{c}2366608 \\
(71 \%)\end{array}$ & $\begin{array}{c}5144798 \\
(100 \%)\end{array}$ \\
\hline Private renting sector & $\begin{array}{c}2839738 \\
(30 \%)\end{array}$ & $\begin{array}{c}3614213 \\
(70 \%)\end{array}$ & $\begin{array}{c}6453951 \\
(100 \%)\end{array}$ \\
\hline Social renting sector & $\begin{array}{c}741116 \\
(8 \%)\end{array}$ & $\begin{array}{c}33376197 \\
(92 \%)\end{array}$ & $\begin{array}{c}4117313 \\
(100 \%)\end{array}$ \\
\hline Owners & $\begin{array}{c}3751641 \\
(40 \%)\end{array}$ & $\begin{array}{c}12559844 \\
(60 \%)\end{array}$ & $\begin{array}{c}16311485 \\
(100 \%)\end{array}$ \\
\hline Total & 9328736 & $\begin{array}{c}18695016 \\
(67 \%)\end{array}$ & $\begin{array}{c}28023752 \\
(100 \%)\end{array}$ \\
\hline
\end{tabular}

Source: Commissariat Général au Développement Durable (Official Agency for Sustainable Development), $2014^{6}$

with the necessity to better grasp peoples' housing vulnerability. In this framework, the notion of comfort has become an issue as an element of economic differentiation of housing and for public policies that aim to gear households practices. Therefore, comfort cannot be studied as a mere technical product of which users have claimed ownership. It entails taking into consideration the features of a commodity socially built up. Comfort standards which have been issued by a set of different actors throughout history, actually distinguish dwellers socially according to their equipment and to their social practices.

Therefore, the notion of comfort does not only relate to technical civilization but to standards set up by stakeholders in the context of housing policies. These policies spur stakeholders and values which make the evolution of housing practices possible. Thus, the different practices in the living space are seen as unequal access to 'good practices'. Then, the stakes of spatial justice are embodied by the normative turn of sustainable development (Agyeman \& Evans, 2004).

In actual fact, all dwellers do not stand the same chances in regard to energy requirements. In France, the housing stock is very different depending on the construction date and the occupancy status.

Thus, according to Phebus's official survey conducted in 2013 by the Official Agency for Sustainable Development, ${ }^{7}$ nearly one-third of housing, more than nine million, offers a low thermal diagnosis, equivalent to the lowest performance labels $\mathrm{F}$ and G. Housing units built before 1948 are slightly more affected, as well as tenants and detached houses. Table 2 below sets out the results of these official statistics conducted by the State by cross-referencing for the whole of the French housing stock (28 million housing units) tax and census data and the results of their energy performance when they are known.

Based on these statistics, the Promotelec Ipsos survey conducted in 2014-2015 and 2016 with one thousand owner-occupants and a dozens of non-directive interviews helps understanding the behaviours of the public. ${ }^{8}$ It is often far from being aware of energy insecurity issues but nevertheless attentive to keep its expenses under control. ${ }^{9}$ The qualitative interviews were conducted with a diversified sample from several generations of owner-occupants from various French regions with different climates. We 
supplemented them with a dozen more conducted with the same public and following the same protocol of semi-directive face-to-face interviews. Households were asked to specify 'what they regarded as comfortable housing' and what they would like to achieve this objective by using all the means available, particularly equipment and renovation projects. Facing technicians concerned with the promotion of home automation our scientific-sociologist consultant role involved enabling dwellers to express their own inclination towards acquiring this 'comfort equipment'.

On the one hand, the satisfaction with the facilities supports a perception of housing. They express a deep desire for a better control of their environment. For many households, comfort means equipment, either in terms of health or in terms of computer equipment to monitor and control energy consumption, the opening and closing of the flats, the arrival of intruders... However, households' definition of comfort does not fit in an ideological framework. For some, comfort relates to the built space ('having room, feeling at ease, being able to move as one wishes to' ${ }^{10}$ ), and to being in the position of customizing one's space ('It's a house that reflects who $I \mathrm{am}^{\prime 11}$ ). Others emphasize sociability ('A comfortable house, I feel at ease in it to entertain"12). Safety and calm ('Comfort at home means being safe, being warm'13) relate to an atmosphere and to a willingness to be isolated: 'Comfort means recharging your batteries when you're at home, not being disturbed by noise. It means feeling good and not being disturbed by neighbors and noise..$^{14}$ Atmosphere, temperature and calm are arguments often mentioned. It is on these points that programming enthusiasts can promise to spare them some anxiety.

Faced with energy transition promoted by public authorities, obedience and compliance with dominant narrative are firstly demonstrated by numerous surveys. According to the Promotelec-Ipsos survey a growing proportion claims to be making at least four eco gestures.

$42 \%$ reduce at the same time temperature, heating time and maintenance, use of kitchen and bathroom equipment

A high proportion also states it is favourable towards using home automation that enables them to monitor their energy use.

Concerning the reported room temperature, the qualitative results of interviews emphasizes a tension between the various expectations of households and actual standards. ${ }^{15}$ As Shove observed (2010), regarding heating practices that are the most indicative of the ambivalence between standards and housing practices, statements show ambiguous results. The thrifty message ('for me comfort doesn't mean having heating and forgetting to put a sweater on. If you put a sweater on you'll be as comfortable, even if the temperature is 2 degrees lower ${ }^{16}$ ) may readily be associated to the 'thermal willingness' one ('We don't want to waste, whether it is 25 or 26 degrees, we are careful, that's why we turn the heating off in the morning and we only turn it back on in the evening. ${ }^{17}$ ). But the 'programming' discourse is actually the most common one, making automation responsible for curbing any non-standard practice: 'It can be set up in no time, depending on the hour and on the temperature I want. ${ }^{.18}$

Ultimately, the analysis of households' definition of comfort and what they claim their practices, actually shows a strong discrepancy. It would have been interesting at this stage to use other means besides discourse to verify this (Goodchild et al., 2014). 
It can therefore be assumed that an implicit symbolic transaction takes place among households between standards and their practices:

Children are asked to be careful. We open the windows in the bedrooms in the morning, and my son, after doing so, would turn the heating on to the max to be warm in his bedroom and I told him that wouldn't be possible anymore! This means explaining it increases the electricity bill, and that he has to find another place, I told him to ventilate his room and then to get dressed in the bathroom. It's only a matter of getting into the habit of doing it. ${ }^{19}$

In this transaction, the ecological argument involves most of the time nothing, but going the extra mile provided comfort is satisfactory for the same cost. What is crucial however is comfort satisfaction, which is part of the promise of comfort the Welfare State has made ever since the Hygienist period. If in return for this promise, households agree to monitor themselves through technical systems, and to limit their consumption, then the challenge of energy transition will have been achieved. If on the other hand the feeling of losing comfort prevails, then the transaction will not be effective. The symbolic dimension of this transaction seems important to us because it reveals the weight of State injunctions and the identity dimension of 'good practices'. It shows how, for the dweller, the notion of comfort is at the centre of a non-explicit negotiation between what can be done thanks to the equipment and what should be done in order to 'dwell well'.

\section{Conclusion: a combination of policies}

This brief socio-historical perspective put forth may be related to the housing regime theory (Moosberger \& Stocker, 2001). It explains how State regulatory actions become incentives and revolve around intricate stakeholders' networks whereas an individualisation of responsibility is taking place. Even if the role of the State is central in the French Housing Regime, the rule of law is shifting from official bodies to be experimented and pre-empted within organisations associating professional and local communities. Unlike the hygienist/period, it is actually thanks to the labels issued by professional organisations that housing quality is assessed, positively, in order to enter the market. Such a plan relies on a network of players that includes, around the contracting authority, organisations that issue the label within which engineers and construction economists are central. The State and local authorities take part in it, the former by incorporating labels in a regulatory form, the latter by establishing more and more demanding local regulation regarding performance and quality. Such public action network involves a process that enables the association of the various actors around the project, including the dwellers. The standard is therefore no longer imposed but is the result of a combination of connections between the actors and the technical tools that enable its implementation.

Having shown how housing policies have gradually incorporated the social, technical and economic aspects of standards, the specificity of sustainable housing policies arises more distinctly. Standard issuance is devolved, dwellers individual empowerment is essential and the notion of energy performance is central to construction and housing. For households, the main goal is to control the environment. This topic can 
be introduced on energy, its cost, and by extension the security of the home and the neighbourhood, and the social environment. This is what distinguishes sustainable housing policies from hygienist policies that focused on State public health protection and from post WWII policies that standardized and equipped the housing stock about to be introduced into the marketplace. In this framework, theories condemning 'neo-hygienist' sustainable urban policies (Tozzi, 2013) do not seem very suggestive to us inasmuch as public health concern is less significant than continuing to promise full comfort while at the same time implementing energy transition. In addition, individual responsibility which is part of the values of sustainable development is miles from the hygienist stance based on imposition. While hygienism imposed practices, environmental neo-liberalism made the inhabitant play a major role in the direction of his policy.

Households who are confronted with injunctive strategies approve of sustainable housing policies and readily display eco gestures and thrifty behaviours, in compliance with these policies. If one should question the discrepancy between what is stated and actual practices, statements also show a yearning for facilities that are supposed to assist households in the monitoring of their energy expenditure and more broadly, control their living space (intrusions). Is this the new perception of comfort? Households' definitions of comfort demonstrate a growing adhesion to the notion of atmosphere and tranquillity. These definitions do not carry thrifty consumption patterns expected by policies. We can therefore assume that an ecological transaction, that is, a silent and implicit negotiation is taking place within households between sustainable housing standards and their actual practices.

However, unlike the widespread presentation of energy transition, households' ability to arbitrate is uneven, if only because of the disparities in the housing stock and in occupancy status. Therefore, excluded from 'good housing' are those who are objectively poorly housed (and poorly heated) because they are victims of segregated housing market processes than those who do not have the supposed skills (or the normative conception of comfort) for to live in a sustainable dwelling. In the future, the success of sustainable housing policies will depend on whether the various expectations in terms of comfort as well as social and space inequalities are taken into account.

In conclusion, comfort standards today have evolved to become an element of economic differentiation drawing on technology, in which housing standards are the outcome of a complex interplay between actors (government and non-government) and technical tools. The costs and practices involved in the new housing norm that emerges are argued to be exclusionary and the authors point towards a discrepancy between sustainable housing standards and actual practices.

Thus, comfort is truly a political issue. Comfort complies: technical devices entail body governability behaviours (Foucault, 2004). Just as Le Corbusier had foreseen it 'the machine for living in', that is collective housing, follows the rhythm of equipment that implies respectful use of the mechanisms. Thus, the vast majority of French owners seem to consent to injunctions regarding energy conservation good practices. They expect more and more the technical equipment to regulate excessive consumption, intrusions, children alone at home and elderly people vulnerability. In 
order to obtain this peace of mind they call 'comfort', they ask for a 'programmed house'. Without the fear of seeing their houses burn down, being flooded or burgled, being able to monitor their children coming back from school as well as their elder relatives, dwellers glued to their 'connected objects' (Atkinson \& Blandy, 2013) look more and more like aristocrats from the 'Old Regime' depicted by Elias (1985). Whereas they used to write down their torments in their diary, it is on a tablet that today's households confess their excesses. A connection can be made between the enthusiasm for the programmed house and for the electronic fortresses of gated communities.

Indeed, the definition of comfort from an equipment manufacturer perspective only reveals a limited aspect of the notion of well-being. Faced with social and spatial inequalities, can housing that cannot provide opportunities and capabilities be defined as comfortable? (Sen, 2008, Clapham, 2010, Coates et al., 2013) Such is undoubtedly the challenge that social sciences hold up to the supposed pure 'technical views' of housing.

\section{Notes}

1. Habitants, habitats et modes de vie " http://www.promotelec.com/wp-content/uploads/ 2016/06/2015-11-05-Conference-de-presse-Les-francais-et-la-domotique-ObservatoirePromotelec-du-confort-dans-l-habitat.pdf.

2. In France, social home ownership is usually to offer loans at low rates to low-income populations

3. The original purpose of the Musée social was to preserve documents from the Social Economy pavilion of the Exposition Universelle (1889).

The Musée social was a private French institution founded in 1894. In the early twentieth century it became an important center of research into topics such as city planning, social housing and labor organization. For many years it played an important role in influencing government policy.

4. http://www.lemoniteur.fr/article/le-cgdd-etudie-les-surcouts-de-construction-des-logementsperformants-compenses-par-les-economies-d-30708520

5. Article 25 - Universal Declaration of Human Rights

Everyone has the right to a standard of living adequate for the health and well-being of himself and of his family, including food, clothing, housing and medical care and necessary social services, and the right to security in the event of unemployment, sickness, disability, widowhood, old age or other lack of livelihood in circumstances beyond his control. http://www.ichrp.org/en/article_25_udhr

6. http://www.statistiques.developpementdurable.gouv.fr/fileadmin/documents/Produits_ editoriaux/Publications/Chiffres_et_statistiques/2014/chiffres-stats534-Phebus-juillet2014b.pdf.

7. The Phébus survey describes the energy performance of the permanents residences. The sample of dwellings is extracted from INSEE surveys. It consists of 8,000 dwellings representative of the regions, climatic zones, types of housing (individual house or collective housing) and years of construction. The themes of the questionnaires focus on the general characteristics of housing and occupants and the official Energy Performance Diagnosis (EPD) to measure the energy performance of housing

8. The methodology of the survey is based on a questionnaire proposed to a population of homeowners in about 30 closed and multiple-choice questions on opinions and practices. The sample is representative of the different types of owners and the housing stock in France: young first-time home buyers, elderly people, recent and old dwellings. This 
questionnaire is completed by a dozen non-directive interviews focusing on automation practices in the home. We completed this qualitative survey by a dozen interviews more focused on the concept of comfort with homeowners.

9. Observatoire Promotelec Ipsos du confort dans l'habitat, op.cit

10. Woman, retired executive from the private sector, 65, lives alone in the centre of Paris

11. Woman, 30, sales assistant in a clothing store, lives alone, owner of a small apartment in a middle-sized town in France

12. Man, 65, former farmer, owner of a large house in the South of France

13. Man, 50, private sector executive lives in a detached house in the Paris suburbs with two children

14. Woman, retired private sector executive, 65, lives alone in the centre of Paris

15. http://www.ipsos.fr/decrypter-societe/2016-05-31-habitants-habitats-et-mode-vie

16. Woman, 50, private sector executive, lives as a couple with no children, owner of an old house in the French Provinces

17. Man, retired local authority middle manager, owner of a detached house

18. Ibid.

19. Woman, married with two children, 35, sales executive, owner of detached house

\section{References}

Agyeman, J. \& Evans, B. (2004), “Just sustainability": the emerging discourse of environmental justice in Britain', The Geographical Journal, 170(2), pp.155-164.

Akrich, M., \& Callon, M., \& Latour B., (2006) Sociologie de la traduction. Textes fondateurs, (Paris: École des Mines de Paris).

Allen, J., Barlow, J., Leal, J., Maloutas, T., \& Padovani, L. (2008). Housing and welfare in Southern Europe (Vol. 16). John Wiley \& Sons.

Angel, S. (2000). Housing policy matters: A global analysis. Oxford University Press.

Atkinson, R., \& Blandy, S. (2013). Gated communities: International perspectives. Routledge.

Bevir, M., Rhodes, R. A., \& Weller, P. (2003). Traditions of governance: interpreting the changing role of the public sector. Public administration, 81(1), pp. 1-17.

Blanc, M. (2004). The changing role of the state in french housing policies: a roll-out without roll-back?. European Journal of Housing Policy, 4(3), pp. 283-302.

Bourdieu, P. (1979) La distinction. Critique sociale du jugement, (Paris: Ed de Minuit).

Bugeja-Bloch, F. (2013). Logement, la spirale des inégalités: une nouvelle dimension de la fracture sociale et générationnelle. PUF.

Clapham D. (2010), Happiness, well-being and housing policy, Policy \& Politics vol 38 no 2 • 253-267

Coates D., Anand, P., Norris M. (2013), Housing, happiness and capabilities: a summary of international evidence and models, International Journal of Energy, Environment, and Economics, 21(3)

Crawford, J., \& McKee, K. (2016). "Hysteresis: understanding the housing aspirations gap", Sociology, pp. 380-385.

Crowley, J-E. (2001). The Invention of Comfort. Sensibilities \& Design in Early Modern Britain \& Early America, Baltimore, Johns: Hopkins University Press

Desrosières, A., \& Naish, C. (2002). The politics of large numbers: A history of statistical reasoning. Harvard University Press.

Driant, J. C., \& Rieg, C. (2004), Les ménages à bas revenus et le logement social. 962, 1-4 (Insee Première).

Elias N. (1985) La société de cour, Paris: Flammarion.

Elkin, S. L. (2015). City and regime in the American republic. University of Chicago Press.

Fijalkow, Y. (1998), La construction des îlots insalubres: Paris 1850-1945. Editions L'Harmattan. 
Fijalkow, Y. (2000). "La notion d'insalubrité. Un processus de rationalization", 1850-1902. Revue d'Histoire du XIXe siècle.

Flamand, J-P. (1989), Loger le peuple, essai sur l'histoire du logement social. Paris: La Découverte

Foucault, M. (2004). Sécurité, territoire, population: cours au Collège de France, 1977-1978. Gallimard.

Goodchild, B., O’Flaherty, F., \& Ambrose, A. (2014). "Inside the eco-home: Using video to understand the implications of innovative housing". Housing, Theory and Society, 31(3), pp. 334-352.

Goromosov, M.S (1954), Principes d'hygiène applicables à l'établissement de norms de microclimate pour les habitations dans diverses zones climatiques. In Etude expérimentale sur la regulation des fonctions physiologique, Moscou et Léningrad, 3, pp. 163.

Groves, R. (2016), Housing and the new welfare state: Perspectives from East Asia and Europe. Routledge.

Harloe, M. (2008), The People's Home: Social Rented Housing in Europe and America. John Wiley \& Sons.

Healy, J. D. (2004), Housing, fuel poverty, and health: a pan-European analysis. Gower Publishing, Ltd.

Howden-Chapman, P. (2004). "Housing standards: a glossary of housing and health". Journal of epidemiology and Community health, 58(3), pp. 162-168.

Jaquot A. (2006), "Cinquante ans d'évolution des conditions de logement des ménages ", Données sociales. La société française, Insee

Kemeny, J. (1987). Toward a theorised housing studies: A counter-critique of the provision thesis. Housing Studies, 2(4), pp. 249-260.

Kemeny, J. (1995). Theories of power in the three worlds of welfare capitalism. Journal of European Social Policy, 5(2), pp. 87-96.

Kemeny, J. (2013). Housing and social theory. Routledge. Première edition 1992.

Lambert, A. (2015). “ Tous propriétaires!”: l'envers du décor pavillonnaire. Seuil.

Latour, B. (1996). "On actor-network theory: A few clarifications". Soziale welt, 369-381.

Latour, B. (2005). Reassembling the social: An introduction to actor-network-theory. Oxford university press.

Le Galès, P. (1995). Du gouvernement des villes à la gouvernance urbaine. Revue française de science politique, pp. 57-95.

Le Goff, O. (1994) L'invention du confort, naissance d'une forme sociale. Lyon: Presses Universitaires de Lyon.

Lévy-Vroelant, C., \& Fijalkow, Y. (2014). "Making new from old in France: urban change through housing renewal in two Parisian districts", in Turkington, R., \& Watson, C. (Eds.). (2014). Renewing Europe's housing. Policy Press.

Levy, A. (2012), Ville, urbanisme \& santé: les trois revolutions, Paris Ed: Pascal.

Magri, S. (1991). Des «ouvriers» aux «citoyens modestes»: Naissance d'une catégorie: les bénéficiaires des habitations à bon marché au tournant du XXe siècle. Genèses, 5(1), pp. 35-53.

McKee, K. (2011). Sceptical, disorderly and paradoxical subjects: Problematizing the "will to empower" in social housing governance. Housing, Theory and Society, 28(1), pp. 1-18.

Miller, R. (1983). The Hoover ${ }^{\circledR}$ in the garden: Middle-class women and suburbanization, 1850-1920. Environment and Planning D: Society and Space, 1(1), pp. 73-87.

Mossberger K., "Urban Regime Analysis », in Jonathan S. Davies, David L. Imbroscio (eds.), Theories of Urban Politics, Second edition, Londres, Sage, 2009.

Mossberger, K., Stoker, G. (2001), " The evolution of urban theory. The challenge of conceptualization», Urban Affairs Review, 36, pp. 810-835.

Pollard, J. (2010). How the state is handling the property crisis in France: A perspective on recent government measures. International Journal of Urban and Regional Research, 34(3), 686-692. 
Renauld, V. (2014), Fabrication et usage des écoquartiers. Essai critique sur la généralisation de l'aménagement durable en France. Lausanne, Presses polytechniques et universitaires romandes, $128 \mathrm{p}$.

Ronald, R. (2008). The ideology of home ownership: Homeowner societies and the role of housing. Springer.

Sellier, H. (1944), « Le logement normal », Cahiers du Musée Social, $\mathrm{N}^{\circ} 1$

Sen, A.K. (2008), 'The Economics of Happiness and Capability' in Bruni, Comim and Pugno (eds.) Capability and Happiness, New York: Oxford University Press.

Shove E., (2003) Comfort, Cleanliness, Convenience, the Social Organization of Normality, (Oxford: Berg Publishers)

Shove, E., Pantzar, M., \& Watson, M. (2012). The dynamics of social practice: Everyday life and how it changes. Sage Publications.

Stone, C. N. (1993). Urban regimes and the capacity to govern: A political economy approach. Journal of urban affairs, 15(1), pp. 1-28.

Torgersen, U. (1987). Housing: the wobbly pillar under the welfare state. Scandinavian Housing and Planning Research, 4(sup1), pp. 116-126.

Tozzi, P. (2013). Ville durable et marqueurs d'un «néo-hygiénisme»? Analyse des discours de projets d'écoquartiers français. Norois, (2), pp. 97-113.

Turkington, R., \& Watson, C. (Eds.). (2014). Renewing Europe's housing. Policy Press.

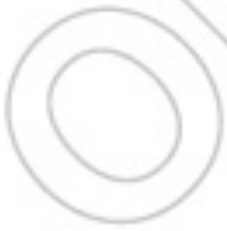

